\title{
Efficiency of root canal cleaning using a single instrument with reciprocating motion systems and full rotation systems: a SEM study
}

\author{
Slavoljub Živković, Jelena Nešković, Milica Jovanović Medojević, Marijana Popović Bajić, Dejan \\ Ostojić \\ University of Belgrade, Faculty of Dental Medicine, Department for Restorative Odontology and Endodontics, Belgrade, \\ Serbia
}

\begin{abstract}
SUMMARY
Introduction Efficient cleaning and canal design present a basic precondition for successful endodontic treatment. The aim of this study was to evaluate, using SEM analysis, the efficacy of cleaning the apical third of the canal with one instrument in both reciprocating motion and full rotation systems.

Materials and methods Thirty (30) single-rooted teeth (upper incisors), extracted due to periodontal reasons, were used and selected in 2 groups. In the group 1, instrumentation was done with a single instrument UNICONE with reciprocal movements (MEDIN, Czech Republic), while in the group 2, a single instrument XPS endo SHAPER (XPS) (FKG, Dentaire, Swiss) with full rotation was used. $2 \%$ solution of $\mathrm{NaOCl}$ and $17 \%$ EDTA solution were used as irrigation agents in both groups. SEM analysis of smear layer in the apical third was done at standard magnification of 1000x and presented on a scale of $1-5$.

Results showed mostly clean canal walls and no smear layer in the apical region in both tested groups. Canal walls were somewhat cleaner after using UNICONE with reciprocal movements (80\%) compared to the canals instrumented with XPS ENDO SHAPER (76\%), but this difference was not statistically significant.

Conclusion Single-file NiTi systems did not remove smear layer completely, but provided efficient cleaning in the apical part of the canal. UNICONE file with reciprocal movements was somewhat more efficient in removing smear layer compared to the full rotation XPS ENDO SHAPER file.
\end{abstract}

Keywords: smear layer; reciprocal movements; NiTi rotating instruments; SEM

\section{INTRODUCTION}

Chemomechanical instrumentation and quality cleaning and shaping of the root canal system are basic preconditions for successful endodontic treatment. NiTi instruments are highly flexible and elastic, and they provide efficient and safe preparation $[1,2]$. However, due to their frequent fracture, their application in curved root canals can be challenging $[3,4,5]$. In order to eliminate the risk during their use, dental technology has developed several new strategies in designing these instruments that include new cross section design of the working part of the instrument, special thermo-mechanical procedure in the preparation of the alloy, and different kinetics of instrument motion in the canal $[2,6,7,8]$.

Introduction of new root canal preparation system, based on the use of reciprocating motion instruments, has opened new possibilities for cleaning and shaping $[9,10]$. Problems related to deformation and fractures of instruments with reciprocal movements are significantly less common compared to instruments with full rotation $[9,10,11]$. In addition, reciprocal movements are based on the technique of balanced forces and imply instrument rotation in the counterclockwise (cutting) direction and much shorter movement in the clockwise direction (relaxation of the instrument), significantly reducing the contact surface between instrument and dentin, and thus torsion stress and cyclical fatigue $[7,9,12,13]$.

Reducing the number of instruments necessary for preparation is also one of the current requirements in chemo-mechanical instrumentation. Instruments with reciprocal movements are most often represented with only one instrument $[9,10,14,15]$. They are made of special NiTi alloys with specific thermal treatment, which significantly increases their flexibility and resistance to cyclic fatigue $[8,9,15,16]$. The results of the research on reciprocal systems have confirmed the benefits of these instruments associated with shorter preparation time $[9$, $12]$, increased resistance to cyclic fatigue $[9,13,15]$, and similar shaping efficiency to full-rotation systems that use multiple files $[9,10,16,17]$.

Complete cleaning of the root canal system is difficult to achieve (especially in the apical third), however data about the efficacy of files with reciprocal movements are very scarce. Numerous studies have confirmed that effective dentin cutting is largely dependent on instrument

Address for correspondence: Slavoljub ŽIVKOVIĆ, University of Belgrade, Faculty of Dental Medicine, Department for Restorative Odontology and Endodontics, 11000 Belgrade, Serbia; slavzivkovic@gmail.com 
itself: material it is made of, design of the working part of the instrument, thread number, top design, special treatment of the surface of the file, and dynamics and kinetics of motion within the canal $[9,10,12,16,18]$.

The aim of this study was to evaluate, using SEM analysis, the efficacy of cleaning the apical third of the canal using two different NiTi rotation systems: one instrument with reciprocating motion and one instrument with full rotation.

The following hypotheses were tested:

1. Reciprocal single-file systems produce less smear layer than rotary single-file systems.

2. Reciprocal single-file systems produce quantities of smear layer that are similar to those produced by single-file rotary systems.

\section{MATERIALS AND METHODS}

Thirty (30) single-rooted teeth (upper incisors), extracted due to periodontal reasons, were used and randomly selected into the two groups. Working length $(1 \mathrm{~mm}$ shorter than the length when instrument appears on the apex) was determined after the formation of the access cavity. A single researcher carried out all canal instrumentation.

In the group 1, instrumentation was done using single instrument UNICONE (25/06) with reciprocal movements (MEDIN, the Czech Republic). After checking the canal patency, the canal was filled with $2 \% \mathrm{NaOCl}$ solution (CHLORAKSID 2\%, Cercamed, Poland) and the instrument placed to the working length (3-5 times) with gentle pulling movements. The canal was washed with $2 \mathrm{ml}$ solution before and after instrumentation. A 17\% EDTA solution (Calcinase, EDTA solution, Lege artis, Pharma $\mathrm{GmbH}$ ) (1 ml) was used for irrigation after sodium hypochlorite. Final rinsing was done with additional $2 \mathrm{ml}$ of sodium hypochlorite solution.

In the group 2, the canal preparation was done with a full rotation single instrument XPS (30/04) (FKG, Dentaire, Swiss). In the canal filled with a 2\% sodium hypochlorite solution instrument was placed to the working length with gentle pulling movements for 1 minute (1012 movements). The canal was also washed with a $2 \mathrm{ml}$ solution before and after the instrumentation. The same procedure was repeated after inserting $17 \%$ EDTA solution $(1 \mathrm{ml})$. Final rinsing was here also carried out with a $2 \% \mathrm{NaOCl}$ solution $(2 \mathrm{ml})$.

Canal instrumentation in both groups was performed with ENDO A CLASS endo motor (Medin, Czech Republic), which has both reciprocal and full rotation options.

Coronal parts of the teeth were cut into the enamel cement junction area, so that each root segment was 12 $\mathrm{mm}$ long. Using a diamond disc, two grooves on the vestibular and oral sides of the teeth were made, and then the root was split with a chisel into two halves. SEM analysis was done only in the apical third ( $3 \mathrm{~mm}$ from the end of instrumentation) (JOEL, JSM, $6460 \mathrm{LV}$, Japan), and 5 standardized microphotographs (1,000 X magnification) were created for each sample, which were then stored, analyzed and evaluated by 2 independent researchers. The presence of smear layer on the canal walls was evaluated according to the criteria of Hilsman et al. [19].

Score 1 - no smear layer, dentinal tubules are open;

Score 2 - some smear layer, several tubules are open;

Score 3 - homogeneous smear layer covers the wall, a few tubules are open;

Score 4 - the entire wall of the canal is covered with a smear layer, there are no open tubules;

Score 5 - non-homogenous smear layer covers the entire wall of the canal.

SEM photographs of the samples (300 images) were examined by two independent researchers. The obtained results were processed in the SPSS 20 program (IBM "Chicago"). The methods of descriptive statistics were used in the statistical analysis, and Hi square test was used for checking the frequency of the findings between the tested parameters.

\section{RESULTS}

The obtained results are shown in Tables 1 and 2 and Figure $1(a, b)$.

Table 1. Evaluation of smear layer in the apical third

Tabela 1. Evaluacija razmaznog sloja u apikalnoj trećini kanala

\begin{tabular}{|c|c|c|c|c|c|c|c|}
\hline & \multicolumn{6}{|c|}{$\begin{array}{c}\text { Score of smear layer } \\
\text { Vrednost razmaznog sloja }\end{array}$} \\
\hline & & $\mathrm{N}$ & $\overline{\mathbf{x}}$ & SD & Med & Min. & Max \\
\hline \multirow{3}{*}{ 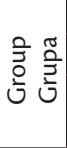 } & UNICONE & 150 & 1.95 & 1.00 & 2.00 & 1.00 & 5.00 \\
\hline & XPS & 150 & 1.95 & 1.00 & 2.00 & 1.00 & 5.00 \\
\hline & $\begin{array}{l}\text { Total } \\
\text { Ukupno }\end{array}$ & 300 & 1.95 & 0.99 & 2.00 & 1.00 & 5.00 \\
\hline
\end{tabular}

Table 2. Evaluation of cleaning quality in the apical third

Tabela 2. Procena kvaliteta instrumentacije apikalne trećine kanala

\begin{tabular}{|c|c|c|c|c|c|}
\hline & \multicolumn{2}{|c|}{$\begin{array}{l}\text { Evaluation of smear layer } \\
\text { Procena razmaznog sloja }\end{array}$} & \multirow{2}{*}{$\begin{array}{l}\text { Total } \\
\text { Ukupno }\end{array}$} \\
\hline & & & $\begin{array}{c}\text { Clean canal } \\
\text { Očišćen kanal }\end{array}$ & $\begin{array}{l}\text { Smear layer } \\
\text { Razmazni sloj }\end{array}$ & \\
\hline \multirow{4}{*}{ 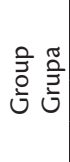 } & \multirow{2}{*}{ UNICONE } & $\mathrm{N}$ & 120 & 30 & 150 \\
\hline & & $\%$ & $80 \%$ & $20 \%$ & $100 \%$ \\
\hline & \multirow{2}{*}{ XPS } & $\mathrm{N}$ & 114 & 36 & 150 \\
\hline & & $\%$ & $76 \%$ & $24 \%$ & $100 \%$ \\
\hline \multirow{2}{*}{\multicolumn{2}{|c|}{$\begin{array}{l}\text { Total } \\
\text { Ukupno }\end{array}$}} & $\mathrm{N}$ & 234 & 66 & 300 \\
\hline & & $\%$ & $78 \%$ & $22 \%$ & $100 \%$ \\
\hline
\end{tabular}

clean canal (score 1, 2)

čist kanal (vrednost 1, 2)

smear layer (score $3,4,5)$

razmazni sloj (vrednost 3, 4, 5)

SEM sample analysis found mostly clean canal walls in the apical region and an identical average rating of the smear layer in both tested groups (Table 1). Clean canal (scores 1 and 2) in the apical third was registered in 80\% of samples where the canal instrumentation was done with the UNICONE instrument with reciprocal movement, and in $76 \%$ of the samples where the XPS instrument with full rotation was used. This difference was not statistically significant (Table 2). Clean walls with a little smear layer in the apical third were most often reported in both groups (score 2): instrumentation with reciprocal 


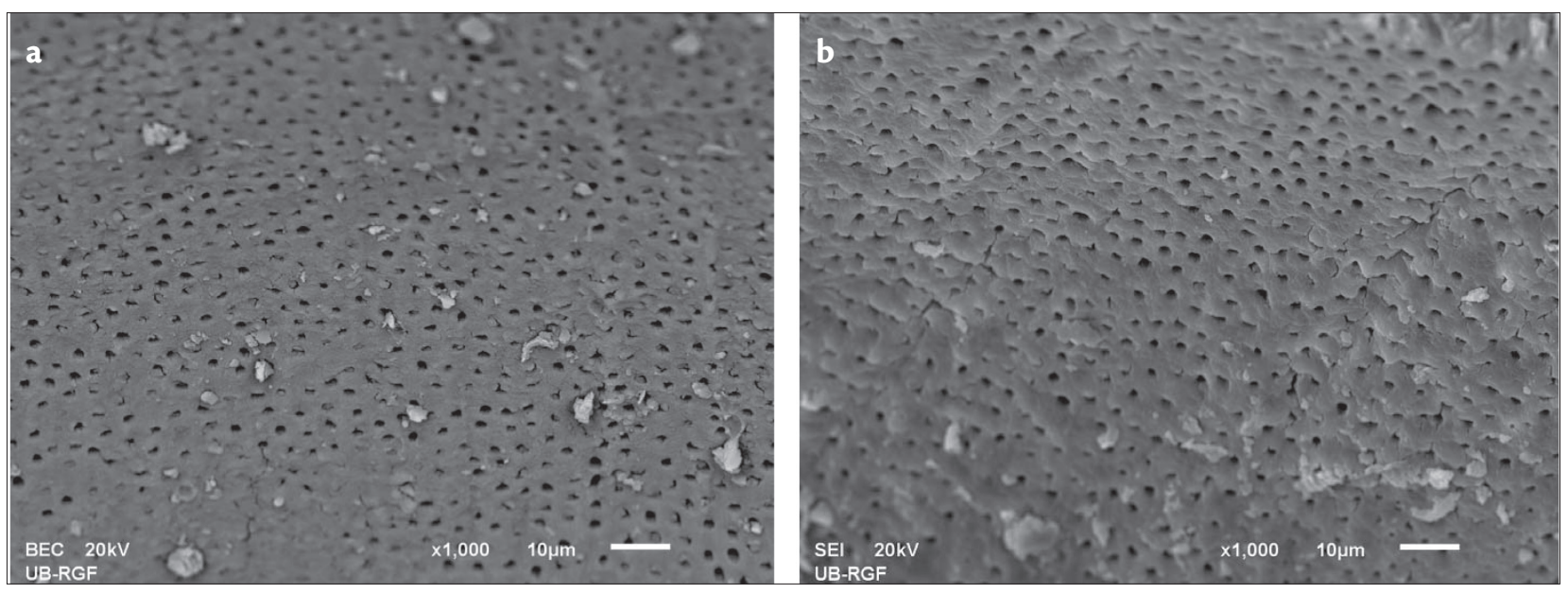

Figure 1. Representative microphotography of smear layer in the apical third

Slika 1. Reprezentativne mikrografije razmaznog sloja u apikalnoj trećini kanala

a) UNICONE file preparation with reciprocal movements (score 2). SEM 1000x

a) instrumentacija je vršena instrumentom UNICONE sa recipročnim pokretima (vrednost 2). SEM 1000x

b) XP-endo SHAPER preparation with full rotation (score 2). SEM 1000x

b) insrumentacija je vršena instrumentom SHAPER sa pokretima pune rotacije (vrednost 2). SEM 1000x

movements of instrument (Figure 1a) and full rotation instrumentation (Figure 1b).

\section{DISCUSSION}

Clean root canal without smear layer is one of the basic preconditions for achieving successful endodontic treatment $[12,16,17]$. The fact is that effective cleaning of the canal system is hardly feasible, especially in the apical third, due to inaccessibility, small diameter of the canal where the amount, concentration and time of exposure of this part of the canal to irrigation solutions is limited $[12,16,17,20,21,22]$.

The main purpose of our study was to compare the effects of two files with different kinetics (reciprocal and full rotation) on the quality of the canal cleaning. An endodontic procedure was performed by a single practitioner on single-rooted teeth (simple canal systems), using an identical irrigation protocol (with an identical amount of solution) to make the preparation process as close as possible to clinical conditions. The results did not show significant differences in the amount of residual smear layer in the apical third between the reciprocal motion file (UNICONE) and the full-rotation file (XPS), so the first hypothesis was rejected. Another hypothesis was accepted because both instruments produced similar amounts of smear layer during the preparation.

Slightly cleaner canal and smaller amount of smear layer in the apical third using the file with reciprocating movements could be explained by design of the working part of the instrument, and its cutting efficiency with increased agitation of the irrigation solution $[9,16,17]$. However, the influence of the file motion dynamics in a small number of realized studies has not been confirmed $[20,23,24]$. There are few studies in the literature that examined the efficacy of reciprocating files regarding the removal of the smear layer from the canal walls [12, $16,17]$. In our study, a new NiTi file (UNICONE), with specific working part design and different helix angle that provides exceptional flexibility and better elimination of dentin debris during instrumentation, was used as an instrument with reciprocal movements. The convex triangular cross section and inactive peak with special thermal treatment of the alloy ensured efficient dentin cutting and rapid and safe preparation with significantly increased bending and cyclic fatigue resistance $[7,9,25]$. More efficient cleaning and less smear layer in the apical region, with the application of UNICONE file, could be explained by good cutting efficiency of the instrument [18] and enhanced agitation of irrigant caused by reciprocal movements in the canal [26]. The results of the current study are consistent with studies that have confirmed the efficacy of reciprocal files in the removal of smear layer and better cleaning of the apical part compared to full rotation instruments $[12,26]$.

However, in the Poggio et al. study, instruments with reciprocal movements produced larger amount of smear layer in the canal system of single-rooted teeth [16]. They explained this finding by the fact that these movements produce "well-packed" smear layer in the canal. Reciprocal movements provide similar effects on the shaping canals just like systems with full rotation [27], but the effect of cutting dentin can be reduced due to prolonged (repeated) clinical use, which may result in larger amount of smear layer on the canal walls.

The efficiency of cleaning the apical region in the full rotation system was also checked after the application of a new instrument with unique XPS geometry. The specific design of the working part with extreme flexibility of the instrument allows changing the shape during rotation in the canal (by its contracting and expanding) and reaching inaccessible parts of the canal [30]. A snakelike XPS shape with its super elasticity and slightly faster rotation speed ensure increased "turbulence" of the irrigation solution, dissolving and removing debris from the canal walls [30].

In our study, small amount of smear layer in the apical region, after the application of XPS, can be explained 
by an adequate dimension of apical preparation (30/04), which provides better effect of the irrigation solution and more efficient removal of smear layer from the canal walls $[17,29,30]$. These results are consistent with studies that assessed the amount of apically extruded debris after the preparation with different instruments, especially XP endo SHAPER [31]. Although the working part of the XPS does not have a significant cut effect, its alternative expansion and contraction in the canal enhance the solubility of irrigants and therefore cleaning of difficult to reach canal zones [29].

\section{CONCLUSION}

Within the limitations of this study, the obtained results showed that single-file NiTi systems (with reciprocal or full-rotation motions) did not remove smear layer completely, but provided efficient cleaning of the apical part of the canal. The file with reciprocal movements UNICONE was somewhat more efficient in removing smear layer from the apical third.

\section{REFERENCES}

1. Lopes HP, Gambarra-Soares T, Elias CN, Siqueira JF Jr, Inojosa IF, Lopes WS, et al. Comparison of the mechanical properties of rotary instruments made of conventional nickel-titanium wire, $M$-wire, or nickel-titanium alloy in R-phase. J Endod. 2013; 39(4):516-20. [DOI: 10.1016/j.joen.2012.12.006] [PMID: 23522548]

2. Shen Y, Zhou HM, Zheng YF, Peng B, Haapasalo M. Current challenges and concepts of the thermomechanical treatment of nickeltitanium instruments. J Endod. 2013; 39(2):163-72. [DOI: 10.1016/j.joen.2012.11.005] [PMID: 23321225]

3. Ankrum MT, Hartwell GR, Truitt JE. K3 Endo, ProTaper, and ProFile systems: breakage and distortion in severely curved roots of molars. J Endod. 2004; 30(4):234-7.

[DOl: 10.1097/00004770-200404000-00013] [PMID: 15085054]

4. Pedullà E, Lo Savio F, Boninelli S, Plotino G, Grande NM, Rapisarda $\mathrm{E}$, et al. Influence of cyclic torsional preloading on cyclic fatigue resistance of nickel - titanium instruments. Int Endod J. 2015; 48(11):1043-50. [DOI: 10.1111/iej.12400] [PMID: 25353957]

5. Wycoff RC, Berzins DW. An in vitro comparison of torsional stress properties of three different rotary nickel-titanium files with a similar cross-sectional design. J Endod. 2012; 38(8):1118-20. [DOI: 10.1016/j.joen.2012.04.022] [PMID: 22794218]

6. Karataş E, Arslan H, Büker M, Seçkin F, Çapar ID. Effect of movement kinematics on the cyclic fatigue resistance of nickel-titanium instruments. Int Endod J. 2016; 49(4):361-4.

[DOl: 10.1111/iej.12453] [PMID: 25816834]

7. Alcalde MP, Tanomaru-Filho M, Bramante CM, Duarte MAH, Guerreiro-Tanomaru JM, Camilo-Pinto J, et al. Cyclic and Torsional Fatigue Resistance of Reciprocating Single Files Manufactured by Different Nickel-titanium Alloys. J Endod. 2017; 43(7):1186-91. [DOI: 10.1016/j.joen.2017.03.008] [PMID: 28527852]

8. Saber SE, Schäfer E. Incidence of dentinal defects after preparation of severely curved root canals using the Reciproc single-file system with and without prior creation of a glide path. Int Endod J. 2016; 49(11):1057-64. [DOI: 10.1111/iej.12555] [PMID: 26426069]

9. Plotino G, Ahmed HM, Grande NM, Cohen S, Bukiet F. Current Assessment of Reciprocation in Endodontic Preparation: A Comprehensive Review--Part II: Properties and Effectiveness. J Endod. 2015; 41(12):1939-50. [DOI: 10.1016/j.joen.2015.08.018] [PMID: 26480824]
10. de Carvalho FM, Gonçalves LC, Marques AA, Alves V, Bueno CE, De Martin AS. Cleaning Effectiveness of a Reciprocating Single-file and a Conventional Rotary Instrumentation System. Open Dent J. 2016; 10:704-13.

[DOI: 10.2174/1874210601610010704] [PMID: 28217185]

11. Varela-Patino P, Martín-Biedma B, Rodriguez-Nogueira J, Cantatore G, Malentaca A, Ruiz-Pinón M. Fracture rate of nickel-titanium instruments using continuous versus alternating rotation. Endodontic Practice Today. 2008; 2(3):193-7.

12. Bürklein S, Hinschitza K, Dammaschke T, Schäfer E. Shaping ability and cleaning effectiveness of two single-file systems in severely curved root canals of extracted teeth: Reciproc and WaveOne versus Mtwo and ProTaper. Int Endod J. 2012; 45(5):449-61. [DOI: 10.1111/j.1365-2591.2011.01996.x] [PMID: 22188401]

13. Kiefner P, Ban M, De-Deus G. Is the reciprocating movement per se able to improve the cyclic fatigue resistance of instruments? Int Endod J. 2014; 47(5):430-6. [DOI: 10.1111/iej.12166] [PMID: 24033466]

14. De-Deus G, Brandão MC, Barino B, Di Giorgi K, Fidel RA, Luna AS. Assessment of apically extruded debris produced by the singlefile ProTaper F2 technique under reciprocating movement. Oral Surg Oral Med Oral Pathol Oral Radiol Endod. 2010; 110(3):390-4. [DOl: 10.1016/j.tripleo.2010.04.0] [PMID: 20727500]

15. Varela-Patiño P, Ibañez-Párraga A, Rivas-Mundiña B, Cantatore G, Otero XL, Martin-Biedma B. Alternating versus continuous rotation: a comparative study of the effect on instrument life. J Endod. 2010; 36(1):157-9. [DOI: 10.1016/j.joen.2009.09.023] [PMID: 20003957]

16. Poggio C, Dagna A, Chiesa M, Scribante A, Beltrami R, Colombo $M$. Effects of NiTi rotary and reciprocating instruments on debris and smear layer scores: an SEM evaluation. J Appl Biomater Funct Mater. 2014; 12(3):256-62. [DOl: 10.5301/jabfm.5000161] [PMID: 24425380]

17. De-Deus G, Marins J, Silva EJ, Souza E, Belladonna FG, Reis C, et al. Accumulated hard tissue debris produced during reciprocating and rotary nickel-titanium canal preparation. J Endod. 2015; 41(5):676-81. [DOI: 10.1016/j.joen.2014.11.028] [PMID: 25670245]

18. Plotino G, Giansiracusa Rubini A, Grande NM. Cutting efficiency of Reciproc and waveOne reciprocating instruments. J Endod. 2014; 40(8):1228-30. [DOI: 10.1016/j.joen.2014.01.041] [PMID: 25069938]

19. Hülsmann MR, Rümmelin CSchäfers F. Root canal cleanliness after preparation with different endodontic handpieces and hand instruments: a comparative SEM investigation. J Endod. 1997; 23(5):301-6. [DOI: 10.1016/S0099-2399(97)80410-4] [PMID: 9545932]

20. Robberecht L, Dehurtevent M, Lemaitre G, Behal H, Hornez JC, Crinquette AC, et al. Influence of Root Canal Curvature on Wall Cleanliness in the Apical Third during Canal Preparation. Eur Endod J. 2017; 2:19. [DOI: 10.5152/eej.2017.16035]

21. Haapasalo M, Shen Y, Wang Z, Gao Y. Irrigation in endodontic. Br Dent J. 2014; 216:299-303. [DOI: 10.1038/sj.bdj.2014.204]

22. Guerreiro-Tanomaru JM, Loiola LE, Morgental RD, Leonardo Rde T, Tanomaru-Filho M. Efficacy of four irrigation needles in cleaning the apical third of root canals. Braz Dent J. 2013; 24(1):21-4. [PMID: 23657408]

23. Zmener O, Pameijer CH, Alvarez Serrano S, Hernandez SR. Cleaning efficacy using two engine-driven systems versus manual instrumentation in curved root canals: a scanning electron microscopic study. J Endod. 2011; 37(9):1279-82.

[DOl: 10.1016/j.joen.2011.05.036]

24. Amaral P, Forner L, Llena C. Smear layer removal in canals shaped with reciprocating rotary systems. J Clin Exp Dent. 2013; 5(5):e22730. [DOI: 10.4317/jced.51170] [PMID: 24455087]

25. Silva E), Villariho LS, Vieira VT, Accorsi-Mendonça T, Antunes HD, De-Deus G, et al. Bending Resistance and Cyclic Fatigue Life of Reciproc, Unicone, and WaveOne Reciprocating Instruments. J Endod, 2016; 42(12):1789-93. [DOI: 10.1016/j.joen.2016.08.026] [PMID: 27776886]

26. Kato As, Cunha RS, da Silveira Bueno CE, Pelegrine RA, Fontana CE, de Martin AS. Investigation of the Efficacy of Passive Ultrasonic Irrigation Versus Irrigation with Reciprocating Activation: An En- 
vironmental Scanning Electron Microscopic Study. J Endod. 2016; 42(4):659-63. [DOI: 10.1016/j.joen.2016.01.016] [PMID: 26906240]

27. Ordinola-Zapata R, Bramante CM, Duarte MAH et al. Shaping ability of Reciproc and TF Adaptive systems in severely curved canals of rapid microCT-based prototyping molar replicas. J Appl Oral Sci. 2014; 22(6):509-15. [DOI: 10.1590/1678-775720130705] [PMID: 24918662]

28. Gambarini G, Giansiracusa Rubini A, Sannino G, Di Giorgio G, Piasecki L, Al-Sudani D, et al. Cutting efficiency of nickel-titanium rotary and reciprocating instruments after prolonged use. Odontology. 2016; 104(1):77-81. [DOI: 10.1007/s10266-014-0183-0] [PMID: 25433447]

29. Lacerda MFLS, Marceliano-Alves MF, Pérez AR, et al. Cleaning and Shaping Oval Canals with 3 Instrumentation Systems: A Cor- relative Micro-computed Tomographic and Histologic Study. J Endod. 2017; 43:1878-84. [DOI: 10.1016/j.joen.2017.06.032] [PMID: 28951035]

30. Neves MA, Provenzano JC, Rôças IN, Siqueira JF Jr. Clinical Antibacterial Effectiveness of Root Canal Preparation with Reciprocating Single-instrument or Continuously Rotating Multi-instrument Systems. J Endod. 2016; 42(1):25-9. [DOl: 10.1016/j.joen.2015.09.019] [PMID: 26549221]

31. Uslu G, Özyürek T, Yılmaz K. Apically Extruded Debris during Root Canal Instrumentation with Reciproc Blue, HyFlex EDM, and XPendo Shaper Nickel-titanium Files. J Endod. 2018 ; 44(5):856-9. [DOI: 10.1016/j.joen.2018.01.018] [PMID: 29550013]

Received: 25.09.2018 • Accepted: 26.11.2018 


\title{
Efikasnost čišćenja kanala jednim instrumentom kod sistema sa recipročnim pokretima i sistema sa punom rotacijom: SEM studija
}

\author{
Slavoljub Živković, Jelena Nešković, Milica Jovanović Medojević, Marijana Popović Bajić, Dejan Ostojić \\ Univerzitet u Beogradu, Stomatološki fakultet, Klinika za bolesti zuba, Beograd, Srbija
}

\begin{abstract}
KRATAK SADRŽAJ
Uvod Efikasno čišćenje i oblikovanje kanala je osnovni preduslov za uspeh endodontskog tretmana. Cilj ovog rada je bio da se SEM analizom proveri efikasnost čišćenja apikalne trećine kanala jednim instrumentom kod sistema sa recipročnim pokretima i sistema sa punom rotacijom.

Materijal i metode Korišćeno je 30 jednokorenih zuba (gornji sekutići) ekstrahovanih zbog parodontalnih problema i podeljenih u dve grupe. U prvoj grupi preparacija kanala je realizovana instrumentom sa recipročnim pokretima - UNICONE (MEDIN, Czech Republic), a u drugoj instrumentom sa punom rotacijom - XP-endo Shaper (XPS) (FKG, DENTAIRE, Swiss).

Kao sredstvo za irigaciju u obe grupe korišćen je $2 \%$ rastvor $\mathrm{NaOCl}$ i $17 \%$ rastvor EDTA. SEM analiza razmaznog sloja apikalne trećine je urađena na standardnom uvećanju od 1000× i procenjivana prema skali od 1 do 5.

Rezultati Istraživanje je ukazalo na uglavnom čiste zidove kanala i bez razmaznog sloja u apikalnoj regiji u obe testirane grupe. Zidovi kanala su bili nešto čistiji posle primene instrumenta sa recipročnim pokretima - UNICONE ( $80 \%$ ) u odnosu na kanale druge grupe gde je korišćen instrument sa punom rotacijom - XPS (76\%), ali bez statistički značajnih razlika.

Zaključak NiTi sistemi sa samo jednom turpijom ne uklanjaju potpuno razmazni sloj, ali obezbeđuju efikasno čišćenje apikalnog dela kanala. Turpija sa recipročnim pokretima UNICONE je bila nešto efikasnija u uklanjanju razmaznog sloja u odnosu na XPS turpiju sa punom rotacijom.
\end{abstract}

Ključne reči: razmazni sloj; recipročni pokreti; NiTi rotirajući instrumenti; SEM

\section{UVOD}

Mašinska instrumentacija danas predstavlja standard u hemomehaničkoj preparaciji, a kvalitetno čišćenje i oblikovanje kanalskog sistema je osnovni preduslov za uspešnost endodontskog tretmana. NiTi instrumenti poseduju izrazitu fleksibilnost i elastičnost, koja obezbeđuje efikasnu i bezbednu preparaciju $[1,2]$, ali zbog čestog loma njihova primena u povijenim kanalima predstavlja značajan rizik $[3,4,5]$. Da bi se eliminisao rizik tokom njihovog korišćenja, dentalna tehnologija je razvila nekoliko novih strategija u dizajniranju ovih instrumenata koje uključuju novi poprečni presek i dizajn radnog dela instrumenta, posebne termomehaničke procedure u pripremi legure, odnosno različitu kinetiku kretanja instrumenta u kanalu $[2,6,7,8]$.

Uvođenje novog sistema preparacije kanala koji se bazira na primeni instrumenata sa recipročnim pokretima ukazalo je na nove mogućnosti u čišćenju i oblikovanju $[9,10]$. Problemi vezani za deformaciju i lom kod instrumenata sa recipročnim pokretima su značajno manji nego kod instrumenata sa punom rotacijom $[9,10,11]$. Naime, recipročni pokreti su bazirani na tehnici balansiranih sila i podrazumevaju rotaciju instrumenta u smeru suprotnom kretanju kazaljke na satu (sekući smer) i mnogo kraćeg pokreta u smeru kazaljke (opuštanje instrumenta), čime se značajno smanjuje površina kontakta instrumenta sa dentinom, a time i torzioni stres i ciklični zamor [7, 9, 12, 13].

Smanjivanje broja instrumenata neophodnih za preparaciju takođe je jedan od aktuelnih zahteva hemomehaničke preparacije, pa su i instrumenti sa recipročnim pokretima najčešće predstavljeni sa samo jednim instrumentom $[9,10,14,15]$. Turpije sa recipročnim pokretima su izrađene od specijalne NiTi legure i sa specifičnim termičkim tretmanom, čime su im značajno povećane fleksibilnost i otpornost na ciklični zamor $[8,9,15,16]$.
Rezultati istraživanja o recipročnim sistemima potvrđuju prednosti ovih instrumenata vezane za kraće vreme preparacije $[9,12]$, povećanu otpornost na ciklični zamor $[9,13,15]$ i slične efekte vezane za efikasnost oblikovanja u poređenju sa sistemima pune rotacije koji koriste više turpija $[9,10,16,17]$.

Iako je potvrđeno da je čišćenje kanalskog sistema zuba teško ostvarivo (pogotovo u apikalnoj trećini), podaci o efektima turpija sa recipročnim pokretima su vrlo oskudni. Brojne studije su potvrdile da efikasno sečenje dentina ipak najviše zavisi od samog instrumenta: materijala od koga je izrađen, dizajna radnog dela, broja navoja, dizajna vrha, posebnog tretmana površine turpije, odnosno dinamike i kinetike kretanja unutar kanala $[9,10,12,16,18]$.

Cilj ovog rada je bio da se SEM analizom proveri efikasnost čišćenja apikalne trećine kanala primenom dva različita NiTi rotaciona sistema: jednog instrumenta sa recipročnim pokretima i jednog instrumenta sa punom rotacijom.

Testirane su sledeće hipoteze:

1. Recipročni sistemi sa jednom turpijom produkuju manje razmaznog sloja nego rotirajući sistemi sa jednom turpijom.

2. Recipročni sistemi sa jednom turpijom produkuju slične količine razmaznog sloja kao i rotirajući sistemi sa jednom turpijom.

\section{MATERIJAL I METOD}

Korišćeno je 30 jednokorenih zuba (gornji sekutići) ekstrahovanih zbog parodontalnih problema, koji su metodom slučajnog izbora podeljeni u dve grupe.

Kod svih zuba je posle formiranja pristupnog kaviteta određena radna dužina (1 mm kraće od dužine na kojoj se vrh instrumenta pojavljuje na apeksu) i potom na vrhu korena po- 
stavljena kuglica roze voska. Preparaciju svih kanala realizovao je jedan istraživač.

U grupi 1 preparacija je realizovana jednim instrumentom sa recipročnim pokretima UNICONE (25/06) (MEDIN, Czech Republic). Posle provere prohodnosti kanal je ispunjen $2 \%$ rastvorom $\mathrm{NaOCl}$ (CHLORAXID 2\%, Cercamed, Poland) i potom instrument nežnim pokretima uvlačenja i izvlačenja plasiran do radne dužine (3-5 puta). Kanal je ispiran sa $2 \mathrm{ml}$ rastvora pre i posle instrumenta. Potom je u kanal ubačen $17 \%$ rastvor EDTA (Calcinase, EDTA solution, Lege artis, Pharma GmbH) i istim pokretima (3-5 puta) plasiran do radne dužine ( $1 \mathrm{ml}$ ). Finalno ispiranje je realizovano sa dodatnih $2 \mathrm{ml}$ rastvora $\mathrm{NaOCl}$.

U grupi 2 preparacija kanala je urađena jednim instrumentom sa potpunom rotacijom XPS (30/04)(FKG, Dentaire, Swiss). $\mathrm{U}$ kanal ispunjen $2 \%$ rastvorom $\mathrm{NaOCl}$ instrument je nežnim pokretima uvlačenja i izvlačenja tokom jednog minuta (10-12 pokreta) plasiran do radne dužine. Kanal je i ovde ispiran sa 2 $\mathrm{ml}$ rastvora pre i posle instrumenta. Isti postupak je ponovljen i posle ubacivanja $17 \%$ rastvora EDTA $(1 \mathrm{ml})$. Finalno ispiranje je i ovde urađeno $2 \%$ rastvorom $\mathrm{NaOCl}(2 \mathrm{ml})$.

Preparacija u obe grupe je realizovana endomotorom ENDO A CLASS (Medin, Czech Republic) koji poseduje i opcije sa recipročnom i opcije sa punom rotacijom.

Krunice zuba su zatim presecane u predelu gleđno-cementne granice, tako da je svaki segment korena imao dužinu 12 $\mathrm{mm}$. Uz pomoć dijamantskog diska napravljena su dva žleba na vestibularnoj i oralnoj strani zuba i potom koren dletom razdvojen na polovine. SEM analiza je urađena samo u apeksnoj trećini (region $3 \mathrm{~mm}$ od granice preparacije) (JOEL, JSM, $6460 \mathrm{LV}$, Japan), a za svaki uzorak je napravljeno pet standardizovanih mikrofotografija (uvećanja 1000 puta), koje su sačuvane i potom analizirane i ocenjivane od strane dva nezavisna istraživača. Prisustvo razmaznog sloja na zidovima kanala procenjivano je prema kriterijumima Hilsmana i sar. [19].

Ocena 1 - nema razmaznog sloja i dentinski tubuli otvoreni;

Ocena 2 - malo razmaznog sloja i nekoliko tubula otvoreno;

Ocena 3 - homogeni razmazni sloj pokriva zid i malo je tubula otvoreno;

Ocena 4 - ceo zid kanala je pokriven razmaznim slojem i nema otvorenih tubula;

Ocena 5 - nehomogen razmazni sloj pokriva celukupan zid kanala.

SEM fotografije dobijenih uzoraka (300 slika) proučavala su dva nezavisna istraživača. Dobijeni rezultati su obrađeni u programu SPSS 20 (IBM „Chicago“). U statističkoj analizi su korišćeni metodi deskriptivne statistike, a za proveru učestalosti nalaza između ispitivanih parametara korišćen je hi-kvadrat test.

\section{REZULTATI}

Dobijeni rezultati istraživanja prikazani su u tabelama 1 i 2 i na Slici $1(\mathrm{a}, \mathrm{b})$.

SEM analiza uzoraka je ukazala na uglavnom čiste zidove kanala u apikalnoj regiji i identičnu prosečnu ocenu razmaznog sloja u obe testirane grupe (Tabela 1).

Čist kanal (ocena 1 i 2) u apikalnoj trećini je registrovan u $80 \%$ uzoraka gde je preparacija kanala realizovana instrumentom sa recipročnim pokretima UNICONE, odnosno u 76\% uzoraka gde je korišćen instrument sa punom rotacijom XPS. Ova razlika nije bila statistički značajna (Tabela 2).

Čisti zidovi sa malo razmaznog sloja u apikalnoj trećini najčešće su ocenjivani ocenom 2 i u grupi gde je preparacija realizovana instrumentom sa recipročnim pokretima (Slika 1a) i u grupi sa punom rotacijom (Slika 1b).

\section{DISKUSIJA}

Čist kanal korena bez razmaznog sloja je jedan od osnovnih preduslova za uspeh endodontskog lečenja [12, 16, 17]. Činjenica je da je efikasno čišćenje kanalskog sistema teško ostvarivo i da je problem apikalne trećine, zbog nepristupačnosti, neadekvatnog dijametra apeksne preparacije, odnosno količine, koncentracije i vremena izlaganja ovog dela kanala rastvorima za irigaciju, dodatno otežan $[12,16,17,20,21,22]$.

Osnovna svrha ovog istraživanja je bila da se uporede efekti dve turpije sa različitom kinetikom kretanja u kanalu tokom preparacije (recipročni i pokreti sa punom rotacijom) i analizira njihov uticaj na kvalitet čišćenja kanala. Endodontsku proceduru je realizovao jedan praktičar na jednokorenim zubima (jednostavni kanalski sistemi) po identičnom protokolu irigacije (i sa identičnom količinom rastvora) kako bi postupak preparacije bio što bliži kliničkim uslovima.

Rezultati ovih istraživanja nisu pokazali značajne razlike $\mathrm{u}$ količini zaostalog razmaznog sloja u apikalnoj trećini između turpije sa recipročnim pokretima (UNICONE) i turpije koja koristi punu rotaciju (XPS), pa je zato prva hipoteza odbačena. Prihvaćena je druga hipoteza jer su oba instrumenta tokom preparacije produkovala slične količine razmaznog sloja.

Iako neznatno, nešto čistiji kanal i manja količina razmaznog sloja u apikalnom delu posle primene turpije sa recipročnim pokretima mogli bi se objasniti, pre svega, dizajnom radnog dela instrumenta i njegovom sečivnom efikasnošću uz pojačanu agitaciju rastvora za irigaciju $[9,16,17]$, s obzirom na to da uticaj dinamike kretanja turpije u malom broju realizovanih istraživanja nije potvrđen $[20,23,24]$.

U literaturi je malo studija koje su ispitivale efektivnost recipročnih turpija u uklanjanju razmaznog sloja sa zidova kanala $[12,16,17]$. U ovom istraživanju je kao instrument sa recipročnim pokretima korišćena nova NiTi turpija (UNICONE) sa specifičnim dizajnom radnog dela i različitim heliksnim uglom, koji obezbeđuje izuzetnu fleksibilnost i bolju eliminaciju dentinskog debrisa tokom preparacije. Konveksni trouglasti poprečni presek i neaktivni vrh uz posebnu termičku obradu legure obezbeđuju efikasno sečenje dentina i brzu i bezbednu preparaciju uz značajno povećanu otpornost na savijanje i ciklični zamor [7, 9, 25].

Nešto efikasnije čišćenje i manje razmaznog sloja u apikalnoj regiji primenom UNICONE trupije moglo bi se objasniti pre svega dobrom sečivnom efikasnošću instrumenta [18] odnosno pojačanom agitacijom rastvora za irigaciju uzrokovanom recipročnim pokretima u kanalu [26]. Rezultati ovog istraživanja su u saglasnosti sa studijama koje su potvrdile efikasnost recipročnih turpija u uklanjanju razmaznog sloja i bolje čišćenje apikalnog dela u poređenju sa instrumentima sa punom rotacijom $[12,26]$.

Međutim, u studiji Poggioa i sar. instrumenti sa recipročnim pokretima su u kanalskom sistemu jednokorenih zuba produ- 
kovali veću količinu razmaznog sloja [16]. Oni ovo objašnjavaju činjenicom da ovi pokreti u kanalu produkuju „dobro upakovan" razmazni sloj.

Turpije sa recipročnim pokretima obezbeđuju slične efekte oblikovanja kanala korena kao i sistemi sa punom rotacijom [27], ali im efekat sečenja dentina može biti redukovan zbog produžene (višekratne) kliničke upotrebe, što za posledicu može imati i veću količinu razmaznog sloja na zidovima kanala.

Efikasnost čišćenja apikalne regije kod sistema sa punom rotacijom proveravana je i posle primene novog instrumenta sa jedinstvenom geometrijom XPS-a. Specifičan dizajn radnog dela uz ekstremnu fleksibilnost instrumenta omogućava menjanje oblika tokom rotacije u kanalu (kontrahuje se i širi) i dosezanje do nepristupačnih delova kanala do kojih većina turpija ne dospeva [30].Zmijoliki oblik XPS-a uz superelastičnost i nešto veću brzinu rotacije obezbeđuje povećanu „turbulenciju“ rastvora za irigaciju, što omogućava da se debris održava u tečnom stanju i manje zadržava na zidovima kanala [30].

Manje razmaznog sloja u apikalnoj regiji posle primene XPSa u ovom istraživanju moglo bi se objasniti i adekvatnom dimenzijom apikalne preparacije (30/04), čime se obezbeđuju bo- lji efekat rastvora za irigaciju i efikasnija elimincija razmaznog sloja sa zidova kanala $[17,29,30]$. Ovi rezultati su u saglasnosti sa nalazima studije koja se bavila količinom apikalno ekstrudiranog debrisa posle preparacije različitim instrumentima, ali je između ostalog ukazala i na značajno manju količinu debrisa u apeksnom delu kanala posle primene XP-endo Shapera [31]. Iako radni deo XPS-a nema izraženi sečivni efekat, svojim naizmeničnim širenjem i skupljanjem u kanalu pojačava rastvarački efekat irigansa i time može značajno uticati na čišćenje teško dostupnih zona kanala [29].

\section{ZAKLJUČAK}

U okviru ograničenja ove studije dobijeni rezultati su pokazali da NiTi sistemi sa samo jednom turpijom (uz recipročne odnosno pokrete pune rotacije) ne uklanjaju potpuno razmazni sloj, ali obezbeđuju efikasno čišćenje apikalnog dela kanala. Turpija sa recipročnim pokretima UNICONE je bila nešto efikasnija u uklanjanju razmaznog sloja i ukazala na čistije zidove u apikalnoj trećini. 